\title{
Wedging Equity and Environmental Justice into the Dis- course on Sustainability
}

\author{
Oscar H. Gandy, Jr. \\ University of Pennsylvania, Philadelphia, USA, ogandy@asc.upenn.edu, \\ http://www.asc.upenn.edu/usr/ogandy/
}

\begin{abstract}
This paper examines the problems and prospects for including meaningful indicators of intragenerational equity into the city based regional planning efforts unfolding around the globe. The central focus of the paper is on the challenges that environmental justice (EJ) activists face as they attempt to frame the problem of equity in ways that the general public would see as not only informative, but compelling.

After reviewing examples of successful efforts to reframe debates about equity, the paper concludes with a discussion of a set of EJ concerns and indicators that have the greatest potential for capturing public attention and commitment despite mounting resistance to the use of redistributive policies in support of sustainability goals.
\end{abstract}

Keywords: Inequality, Equity, Environmentalism, Sustainability, Social and Economic Indicators, Measurement, Framing, Reframing, Environmental Justice, Activism, Social movements, Planning, Policy Formation

Acknowledgement: An earlier version of this paper was presented to the Environment, Science and Risk Communication Working Group of IAMCR at the Istanbul conference, 2011. This modified version reflects the insightful comments and suggestions from two anonymous reviewers. Their contributions are much appreciated.

\section{Introduction}

Sustainability has become a term of art, although there is very little agreement on just precisely what the term is supposed to include, and how it might be measured as an aid to the assessment of policies designed to achieve it. This paper examines the problems and prospects for including meaningful indicators of intragenerational equity into the city-based regional planning efforts unfolding around the globe. The central focus of the paper is on the challenges that environmental justice activists face as they attempt to frame the problem of equity in ways that the general public would see as not only informative, but compelling.

The selection of indicators for inclusion in development planning scenarios is constrained in part by the relative absence of data about economic and social disparities among the resources usually relied upon for land use and transportation planning. In addition, there continues to be disagreement about the nature of the factors that actually cause, or produce the relatively few disparities that are routinely captured within official statistics.

The environmental justice (EJ) frame has been described in terms of its history and in terms of its limited success in capturing the attention of the news media. Its success in capturing a place on the public issue agenda, even among those who are at least marginally concerned about the environment is even more limited. Among those who have mobilized in support of environmental sustainability, most have tended to discuss their interests in equity in intergenerational terms, as is reflected in its standard definition in the 1987 Brundtland Commission Report (Brundtland 1987) that defined sustainable development as that which "meets the needs of the present without compromising the ability of future generations to meet their own needs." 
Environmental justice activists are more concerned about focusing public attention on the maldistribution of ecological harms in the present in ways that further burden communities already disadvantaged structurally by race, gender and social class. Their arguments are often framed in terms that reflect the civil rights heritage of the movement's traditional leaders.

After reviewing examples of successful efforts to reframe debates about equity, the paper concludes with a discussion of a set of EJ concerns and indicators that have the greatest potential for capturing public attention and commitment despite mounting resistance to the use of redistributive policies in support of sustainability goals.

\section{Background}

The publication of the Brundtland Commission's report in 1987 marks the emergence of sustainable development as an international policy goal (Redclift 2005). The definition presented by the UN Commission focused primarily on the relationships between present and future generations. In some constructions and extensions, this linkage implies a kind of intergerational equity, in that each generation should be able to pursue its own interests, despite the fact that they are likely to differ from the interests of future generations.

Intragenerational equity was also raised as a concern through references made to the needs of the "world's poor." Although this working definition has been criticized for its imprecision as well as for its failure to address inherent contradictions between growth and environmental sustainability (Redclift 2005), many recognize that its broad acceptance depended on a certain level of strategic ambiguity regarding this and other fundamental tensions (Hopwood, Mellor and O'Brien 2005; Sneddon, Howarth and Norgaard 2006).

\subsection{Sustainability}

The meaning of sustainability has changed over time, in part as a response to rather dramatic socioeconomic and technological shifts that developed in the 1980 s along with a rise in the importance of markets, neoliberalism, and neoclassical economics as guiding principles for state action. One assumes that continually evolving notions of sustainability would reflect shifting points of emphasis on the status of the environment, the economy, and the equitable sharing of the benefits and burdens within each.

In the view of some, relations between the "three pillars" of sustainability: economic, social and environmental, have shifted so that the economic dominates, followed by the social, with environmental concerns becoming marginalized to a great extent (Adams 2006).

Rarely have the promoters of the idea of sustainability explicitly identified the ideological basis upon which their policy recommendations had been built. However, the role played by this powerful constraint has occasionally been identified in the discourse and documents that have been produced along the way (Giddings, Hopwood and O'Brien 2002; Davidson 2011).

Fundamental shifts in the ideological orientations most common within the development planning regime have been accompanied by an increased emphasis on problems of measurement and assessment of governmental performance. At the same time, arguments about power and distributional equity appear to have been suppressed (Redclift 2005, 218). This marginalization is clearly evident in the fact that the most often cited measures of sustainability tend not to include distributional measures, or other commonplace indicators of inequality between persons and places (Singh, et al. 2009).

Fortunately, periodic international events, such as the United Nations' Earth Summits, have helped to stimulate and revive public and governmental interest in addressing some of the more consequential problems of inequality in the planning of economic developments that would have otherwise have slipped from view (Quental, Lourenco and daSilva 2011).

It is also true that over time, the terms used to characterize, and thereby asses the status of individual nations or the global system as a whole, have come to mean different things, depending upon the perspectives of the users. As Michael Redclift $(2005,223)$ puts it: "if you view sustainability as sustaining households and people, then the distribution of resources and rights in them is central to your objectives. If however, you view 'sustainability' as the 
protection and conservation of the environment, then 'justice' consists primarily of ensuring it continues to play its vital ecological function." This distinction does not include approaches to sustainability that call attention to the many dimensions along which people in households in different communities actually face different threats and opportunities for sustaining themselves. Nor does it address the limitations on their ability to use the law to change their circumstances or their futures (Popescue and Gandy 2004).

Many of the researchers and activists who have been seeking to elevate the position of equity in the sustainability framework have adopted the concept of "just sustainability" as a strategic move in what they see as the right direction (Agyeman, Bullard and Evans 2002; Agyeman and Evans 2003; Pavel 2008). An emphasis on the procedures through which environmentally relevant enablement and constraints are established is seen to be useful in reminding us that inequalities in power tend to be reflected in the inequitable distribution of environmental harms and ecological burdens. It is on the basis of that realization that the pursuit of just sustainability is understood to require mounting challenges to the underlying systems of governance under which environmental policies come to be negotiated and implemented.

\subsection{Measurement and Indicators}

The development of indicators of environmental risk or sustainability continues to be marked by inter- and intra-disciplinary contention and debate. A good part of the disagreement surrounds the interests and uses to which these indicators are likely to be applied (Mayer 2008). Some of the greatest concern arises in relation to the disputes about the appropriateness of particular statistical indexes as tools for policy and planning (Barnett, Lambert and Fry, 2008; Boulanger 2008). Political as well as scientific conflict also arises with regard to the assignment of appropriate weights to the individual measures included within an index.

For example, vulnerability, and its opposite, resilience, have emerged as important frameworks through which to assess the differences within and between societies in terms of their exposure to and management of risks and hazards in the environment (Eakin and Luers 2006; Nelson, Adger and Brown 2007). Some researchers who are concerned about equity "use the term vulnerability when describing how social constructs of race and class can amplify the effects of environmental exposures" (Morello-Frosch, et al. 2011, 882).

Different, but no less spirited debates have developed around the utility of particular measures when making international, or inter-regional comparisons. While the difficulties in using standard indicators to assess the extent of the inequities in income, wealth, and quality of life are quite substantial, even greater difficulties arise when such measures have to be evaluated as tools that might help in the assessment of inter-generational equity. There simply is no solid basis for estimating what future generations might require as a basic necessity of life (Okrent 1999). It makes little sense to assume that some ecological indicator, such as the loss of forests, open space, or recreational opportunities would be of a constant or equal value across generations (Pan and Kao 2009).

The estimations of comparative value would of necessity incorporate estimates based on predictions of the likely status of forests and open space in the not too distant future. At the same time, we understand that those predictions are highly speculative, even though estimates regarding the nature of future states of the environment continue to be made on the basis of sophisticated scenario analysis techniques (Pulver and VanDeveer 2009). Predictions regarding comparative access to environmental resources and exposure to associated risks continue to be quite rare.

Paul Baer (2009) discusses the role that equity plays in some of the scenarios used to represent alternative futures in terms of green house gas emissions (GHGs) and their consequences. It has also been suggested that because of the importance of scenarios to policy development, implementation and evaluation, it will be important for researchers guided by environmental justice concerns to determine "how scenarios engage, reproduce, and/or challenge global patterns of inequality, representation, and resource consumption" (Pulver and VanDeveer 2009, 10). 
Further complications are raised for considerations of equity, in that traditional average or per capita measures ignore differences in the outcomes or impacts likely to be experienced by different segments of the population (Dilworth, et al. 2010, 31). However, one measure of income inequality, the Gini coefficient, is routinely used in the assessment of scenarios that are evaluated in terms of equity, or fairness (Baer 2009). The application of this measure beyond fundamentally economic measures, such as well-being or happiness remains quite limited.

An international commission (Stiglitz, Sen and Fitoussi 2009) is bringing considerable attention and resources to bear on the evaluation of measures that would help us to move beyond the limited information provided by measures like Gross Domestic Product (GDP). The Stiglitz Commission's goals included a dramatic shift in emphasis away from traditional measures of production and consumption, toward indicators of their consequences, such as might be reflected in measures of "well-being" (Stiglitz, Sen and Fitoussi 2009, 12-15). A substantial part of the Commission's effort has been focused on the development of measures of equity and inequality.

\subsection{Equity and Inequality}

Equity and inequality are concerns that operate on two related, but distinct dimensions (Hopwood, Mellor and O'Brien 2005; Povlsen, Borup and Fosse 2011). Equity is frequently used to refer to the fairness of distributions of resources and goods and services. It is also used with regard to the nature of the procedures by which interested parties have been allowed to participate in deliberations and decisions about these distributions. It is less often used in relation to the equality of the results of the policies, procedures and institutions that control these distributions.

Unfortunately, we lack a firm basis upon which to base assessments of the relationship between inequality and fairness (Walker and Eames 2006). In part this reflects the absence of conventional metrics for equity that might support empirical assessments of the relations between equity and inequality (Polvsen, Borup and Fosse 2011, 53). This also reflects the influence of distinctions that are drawn between considerations of inequality as a morally repugnant social status, and considerations of inequality as a relationship that generates a host of other socially unacceptable consequences (Wade 2007; Wilkinson and Pickett 2009).

The presence of inequalities in access to basic goods is routinely characterized as an injustice, in part because in the view of some, that a just society would not tolerate unequal access to health care, or political representation. In addition, access to fundamental resources, goods and services are rarely discussed in terms of equality, instead they tend to be debated in terms of minimal requirements.

Still, in the absence of some conventional standard for determining when some inequality is an injustice, we are unable to determine which disparities, or gaps will be characterized as unjust or unfair and deserving of a policy response (Bithas 2008: 225). The traditional opposition that gets drawn between equity and efficiency re-emerges in the context of sustainability when efficiency is defined in terms of economic growth and development. The conflicts between equity and efficiency are distorted still further when concerns about preserving the environment are placed within the mix (Budd, et al. 2008, 258).

Considerations of equity also tend to generate problems for the application of traditional forms of benefit/cost analyses, because of the fact that in the environmental realm, as in many others, those who pay the costs or bear the burdens are rarely the same persons, or from the same groups who derive the benefits (Farrow 1998). Nevertheless, mainstream economists seem to be comfortable with the conclusion that equity and efficiency are largely incompatible. Perhaps this is because considerations of economic efficiency have come to dominate the policy debates in which the views of economists have come to carry so much weight (Bithas 2008).

Early on, the US Environmental Protection Agency (EPA) indicated that the state of environmental equity could be assessed through periodic equity "audits": "Such audits would focus on broad issues of environmental equity such as: the social and geographic distribution 
of benefits and burdens, the allocation of scarce resources for risk reduction/management, and of communities' participation in risk allocation decisions which could affect the quality of their lives" (US EPA 1992, 71). This is a carefully tempered articulation of a central frame of environmental justice, but it is not one that has attracted many followers.

However it is measured, it is clear that the levels of poverty around the globe continue to be quite high, while the extent of inequality actually appears to have increased more substantially (Adams 2006; Dollar 2007; Sutcliffe 2007). Of particular relevance is the fact that in recent analyses we see that it is in the wealthier nations, such as the United States, where levels of inequality have increased most dramatically over the period during which the pursuit of sustainability has become such a global policy concern (Hacker and Pierson 2010).

Despite increased attention being paid to rising levels of inequality, it is not clear that public concern has kept pace (Gandy 2013). In a report on trends in political attitudes among Americans, the Pew Research Center reported a substantial decline in the share of the population that sees the nation divided between the "haves" and the "have-nots" (Pew 2009, 712). Of course, the amount of attention focused on the problem of inequality by the "Occupy" movement has been limited in part by its strategic choice to emphasize the extreme disparities between the $1 \%$, and everyone else in the wake of a global recession attributed to financial speculation (Gamson and Sifrey 2013; Van Stekelenburg 2012). However, such a gross distinction between the super-rich and the rest of us makes it difficult to appreciate the massive inequalities that exist among the $99 \%$. Those difficulties are greatly magnified when comparisons are made at the global scale.

As Nancy Fraser (2007) reminds us, it is no longer reasonable to assume that the actors that may be responsible for the generation of environmental harms, such as those associated with climate change, would be members of the same nation state as those who suffer the most. There is little doubt that "decisions taken in one territorial state often impact on the lives of those outside it, as do the actions of transnational corporations, international currency speculators and large institutional organizations" (Fraser 2007, 253). As a result, one of the problems that will have to be addressed is the identification of an appropriate venue within which victims can be compensated for the harms they suffer, and where future harms can be limited by constraining the behaviours of those likely to be responsible.

\subsection{Distribution of Benefits and Harms}

Although the primary lens through which environmental inequality is viewed is one that focuses on the inequality of the exposures to harm experienced by people and communities, some researchers have argued that inequality can also be used as a frame through which to understand the distribution of harms to the environment itself (Boyce 2008)

Within consideration of these various distributions, it is also suggested that it is necessary for observers to consider relevant outcomes, or impacts on the quality of life that accompany differential access to resources, experiences, and relationships. This is especially true with regard to those segments of the population that are already burdened by deficits in basic needs (Kreig and Faber 2004; Gandy 2009). As has been widely noted, "methods of cumulative impact assessment are currently undeveloped and often reliant on simplistic models of what may be intensely complex processes and interactions" (Walker and Eames 2006, 8).

Understanding the nature of vulnerability to environmental hazards involves the incorporation of information about specific populations in specific locales. It also requires including information about differences in their resilience or adaptive capacity (Eakin and Luers 2006). We note, for example, that efforts to explain health disparities have recently been focused on identifying patterns of exposure to an expanding list of environmental toxins. However, additional concerns have arisen with regard to the relative absence of health affirming resources and opportunities within their communities (Brulle and Pellow 2006; Cutts, et al. 2009).

In the same way that many have responded to challenges to the utilization of "race" as a basis for comparing disparities in health, wealth and happiness because there is arguably greater variance within, rather than between races (Gandy, 2009, 35-49), our assessments 
of inequality between nations may also need to be set aside in order to focus on the more critical disparities within them.

\section{Environmental Justice}

The dominant framework for exploring the relationship between inequality and concerns about the natural environmental is that of environmental justice (EJ). Dorceta Taylor (2000) describes the path through which the EJ paradigm or framework unfolded as it achieved an influential position within the environmental discourse of the 1990s. Most reviews of this historical period comment on the transformative impact of the President Clinton's issuance of an Executive Order (Clinton 1994) establishing widespread responsibility for Federal agencies to "make achieving environmental justice a part of its mission" especially with regard to the impacts of their programs on minority and low income communities. Although Clinton's initiative served to replace references to "environmental racism" with reference to environmental justice, the result can be seen as expansionary, bring concerns about class into more explicit connection with concerns about race and ethnicity (Popescu and Gandy 2004, 144-145). As a result, at least in the United States, the "environmental justice communities" that became the focus of government attention and legal action tended to be composed primarily of people who were both poor, and racial or ethnic minorities (Kang 2009).

Although the emphasis on government agencies and programs established by Clinton's Executive Order raised the level of public awareness of the role of played by government regulators and regulatory decisions, it took activist social movement organizations (SMOs) to bring attention to bear on the activities of domestic and transnational corporations that largely determined the distributions of environmental harms (Simon, 2000).

The contributions of Robert Bullard $(1990 ; 1993)$ to the development of this movement are especially noteworthy. Members of the EJ movement (EJM) point with pride to a number of early accomplishments (Bullard and Johnson 2000) that include landmark court decisions supporting their opposition to the siting of hazardous waste processing facilities in African American communities. Under the umbrella of the EJM, we also see claims being made with regard to principles of "climate justice," such as those made in response to catastrophic weather events attributed with climate change (Dawson 2010).

The failure of government agencies to plan for, or respond to environmental disasters, such as the massive hurricane named Katrina that wrought such destruction upon the poor African Americans in New Orleans and the Gulf of Mexico, still stands as a prime example of the kinds of environmental injustice that helped to expand the scope of the EJ framework in the US (Colten 2007).

Although many of the concerns of activists who had mobilized against environmental racism (Bullard 1993), were to some degree included under the master frames of the EJM, many still contend that there are important distinctions to be maintained (Holifield 2001). In part, this reflects the realization that communities defined by race or ethnicity are more likely to bear the burdens of cumulative environmental insults than communities defined by gender or social class (Krieg and Faber 2004; Gandy 2009).

Later assessments of this history (Sze and London 2008) emphasize the challenges the movement faced as its framework was applied to new issues, populations, locales and sites of contention (Agyeman, Bullard and Evans 2001; Popescu and Gandy 2004).

While racial discrimination actually plays a significant role in the distribution of environmental insults in a number of European states, it is far more common for EJ efforts in the European context to be focused on issues of class exclusion linked to the political economy of a particular neighbourhood, city or region (Agyeman, Bullard and Evans 2001).

Environmental insults tend to be associated with particular places, and indirectly, with the kinds of people who make their homes in those places (Walker 2009b). Research that attempts to explain the distribution of harms and benefits as a function of place routinely explores the extent to which those distributions vary with race, ethnicity, and social class (Downey and Hawkins 2008; Morello-Frosch, et al. 2011). 
William Budd and his colleagues (2008) remind us how little we actually know about the factors that help to shape how different urban areas respond to the challenge of achieving sustainability. Critics note that there is a tendency for elite oriented planning to favour forms of "green gentrification" that put affordable housing at a premium, and thereby beyond the reach of the poor (Budd, et al. 2008, 266).

It is certainly the case that the nature and distribution of environmental inequality varies among metropolitan areas, but what apparently remains beyond the easy reach of measurement and analysis is the role that race, ethnicity, and income inequality play in determining the level and character of the inequities that each city presents to its observers.

Gordon Walker (2009a) has described how the environmental justice frame has developed in distinctive ways in different regions across the globe. He notes that although most national frameworks reflect the historical influence of the EJM in the US, there are important differences that have emerged, especially with regard to the presence or absence of racial or ethnic identity as subthemes.

Recent expansions in the scope of concerns being negotiated under the banner of environmental justice include the efforts to introduce a mechanism for establishing and enforcing the rights of nature. However, we are reminded of the fact that nature is silent. It cannot express its views directly as human subjects do; at least not in ways that command respect within debates over rights and responsibilities that human beings have with each other (Manes, 1992).

Hundreds of communities in the US, and the people of Ecuador have passed ordinances, and constitutional provisions establishing the rights of nature with the assistance of the Community Environmental Legal Defense Fund (CELDF). However, the protection of those rights depends upon arguments set forth by human advocates (Burden 2010). While debates about the nature of those rights, and who must bear the responsibility for defending them will no doubt continue, arguments about inequality between humans and other entities in the natural realm have yet to be framed as an injustice in ways that can command much time on the floor.

\section{Reframing Sustainability}

With increased media coverage of sustainability as a concept and as a social policy concern (Holt and Barkemeyer 2012), it seems likely that efforts to reframe the discussion will involve attempts to provide targeted messages about the importance of equity as an aspect of its identity. To the extent that sustainability is presented in the media in the context of international policy debates, or in response to critical events, such as natural disasters increasingly linked to climate change, the opportunities for attracting media attention to the nature and consequences of inequality still appear to be somewhat limited (Holt and Barkemeyer 2012).

It has been suggested that the three pillar approach to sustainability (economy, society, environment) should be expanded to six main policy pillars, among which "developing human capital" might serve to elevate a focus on equity in the context of human rights and political liberties (Quental, Lourenco and daSilva 2011, 27). The United Nations' commitment to monitor progress toward achieving a set of comprehensive development goals suggests that its activities might also be identified as a target for efforts to reframe and reactivate the global commitment to equity (Jensen 2010).

In the United States, a growing interest in the development of comparable indicators of sustainability has led to the development of a "community rating system" being pilot tested in 30 cities. "Equity \& Empowerment" has been identified as one of the eight focal areas, and Environmental Justice is one of a set of measurable goals and objectives (STAR Communities 2012). The fact that participating communities would be rated on their performance on a common set of measures, among which assessments of equity in relationship to a commitment to environmental justice and equitable access to resources, does suggest that the struggle to reframe sustainability has already begun in important ways in the US (Star Communities 2012, 48). 


\subsection{Framing Social Problems}

It is generally understood that not all social problems can be framed in quite the same way. In general, framing efforts are focused on establishing the nature of the problem, assigning causal responsibility, and identifying the most reasonable strategies or policies for bringing those problems under control.

To a great extent, environmental concerns have been presented in the context of quite sophisticated arguments about the implications that can be derived from the "facts" that have been gathered by researchers. Much of the debate is about how these facts should be interpreted. The potential for conflict over those interpretations is especially high when the facts are supposed to inform policy about the management of risk (Giddens, 2009; Miller and Reichert, 2000).

Because environmental regulation implicates the economic interests of investors and dominant firms in so many sectors of modern capitalist economies, substantial commitments of time and resources will continue to be made in an attempt to shape public opinion in support of, or in opposition to particular policy options (Gandy 1982; Pan and Kosicki 2001).

Continuing debates about the nature of climate change, the extent of human influence, as well as the implications of these changes for weather and other environmental consequences, have been the target of strategic attempts to control the framing of the problem and its solutions. Considerable resources have been directed toward characterizing the facts and the scientists that generate and interpret them as being wrapped in uncertainty, if not distorted by falsehoods designed for misdirection (Nisbet 2010).

\subsection{Framing and Social Movements}

Robert Brulle (2010) has identified eleven "significant frames" that define the major segments or divisions within the environmental movement. While there is no discursive frame within this set that captures the core values of those activists who are most concerned about environmental justice, or "just sustainability," Brulle does find a cluster of concerns that have converged around the idea of environmental justice and the need for "fundamental social change" (Brulle 2010, 386).

Although the EJ frame has gained visibility in relation to a limited number of issues in which claims of injustice are easily buttressed by images of sympathetic victims, and heartless corporate managers, or disinterested regulators, the injustice frame's impact and reach beyond these cases has been limited. It has been far more difficult to raise injustice claims with regard to climate change and other issues that have diffuse and temporally distant impacts, and multiple sources of harm, threat, or risk (Vandenberg and Ackerly 2008).

Benford and Snow (2000) have extended the earlier contributions of Snow, et al. (1986) in characterizing the approaches taken by social movement organizations (SMOs) to utilize message framing as a resource for attracting, motivating, and mobilizing support, as well as for shaping the public's response to critical policy debates.

Collective action frames are used by SMOs to move both associates and institutional targets toward recognition of the presence of an injustice at the heart of the social problems being debated (Noakes and Johnston 2005; Manheim 2011). Often, the struggle between SMOs and their targets is over the association of particular values with an institutional actor they desire to defend, punish, or transform.

SMOs attempting to deal with environmental justice concerns have to struggle continually with the problems involved in building coalitions across what are often substantial barriers to convergence in worldview, or ideological perspectives. Often these political orientations are derived from vastly different concrete social experiences (Beamish and Leubbers 2009).

It seems clear that social position helps to shape the way members of different groups understand the nature of the problems, and the solutions that they believe are available to them. Among the many positional differences that can get in the way of successful collaboration between groups, the time-value of outcomes and objectives is especially important. We note for example that: "working class social movements emphasize tangible and immediate outcomes such as economic gain, while middle class movements tend to emphasize univer- 
sal values and less immediate goals like education and legal challenge" (Beamish and Leubbers 2009, 652).

\subsection{Reframing Inequality}

Inequality, as a threat to well-being, or quality of life around the globe has been introduced into the media stream by the publication of critical work that expands our understanding of the relationship between inequality and social dysfunction. Richard Wilkinson and Kate Pickett $(2009,495)$ have identified an extensive list of social problems that are associated with income inequality.

Of course, it will not be enough to remind people that inequality is associated with poor health and other social problems. It will be necessary to offer compelling explanations of the processes that generate this almost universally observed pattern (Lynch, et al. 2004). It will be especially important to focus these explanations and examples on the characteristics of the social, economic and political environments in which the least fortunate make their lives.

Promising areas for the development of framing strategies appear to be in the domain of social capital and interpersonal trust. However, social status differentiation reinforced by mass media promotion of conspicuous consumption (Dauvergne 2010) is amplified through social media. This suggests that many of these particular aspects of the social environment will need to be incorporated more skilfully into the reframed discourse of sustainability (Adams 2006).

Despite the fact that the new media have been identified as having played a central role in the emergence and meteoric rise of the multifaceted \#Occupy movement (Juris 2012), we are also reminded of the environmental burden that this rapidly expanding infrastructure of media represents (Maxwell and Miller 2012). We understand that challenging the unsustainable production and consumption of goods and services that the mass media promote as a way of life, is a battle that has barely been met. But, as Maxwell and Miller suggest, we have not even begun to consider the myriad ways in which the consumer electronic media technologies themselves represent massive and, characteristically maldistributed threats to the carrying capacity of natural systems around the globe.

Part of the difficulty that activists will have to face as they attempt to reframe public thinking about inequality is the fact that the news media, like other institutions in society (Bartels 2008), tend to be more responsive to those who are privileged, than they are to those who are in the greatest need (Carragee and Roefs 2004).

Thus, as John Pollock's (2007) extension of the community structure approach (Tichenor, Donohue and Olien 1980) suggests, "the higher the proportion of privileged groups in a city, the less favorable the reporting on [...] issues challenging a valued way of life for privileged groups" (Pollock 2007, 260). This suggests that framing arguments and stories that emphasize the hardships and misfortunes of unsympathetic groups, or represent threats to the comfortable lives enjoyed by a nation's elite, is not likely to find an easy pathway to the audiences that activists most desperately need to reach (Manheim 2011).

At the same time, studies of media and community structure suggest that stories framed in terms of more so-called "legitimate" interests of the poor, such as expanded employment opportunities, are more likely to be distributed by media outlets in markets where the impact of poverty is more visible (Pollock 2007, 193).

\section{Wedging Equity and Justice into Sustainability}

Because of the complex network of interests that are involved in environmental debates, it is often necessary for SMOs concerned about social justice and inequality to find ways to limit the harmful impact of conflicts between potential members of an emergent coalition (Pellow 1999). Some suggest that the challenge is one of finding a "new identity" under which seemingly disparate views can be integrated into an approach that binds cognitive, affective, and behavioural dimensions of a commitment to a common goal (Pastor and Ortiz 2009).

We understand that the challenge we face in achieving sustainability is based in the kinds of choices that we are able to make as individuals, and as political collectives that operate at 
the local, regional, national and international levels. These choices are about goals as well as about means. They have to be guided by values (Paehlke 2000) as well as by our understanding of quite complex systems of relationships.

The literature on strategic framing has largely been focused on changing attitudes, rather than on shaping the behaviour of citizens, legislators, or regulators. Advocates not only have to affect public understanding of the factors that threaten the goal of an equitable or just sustainability, but they also have to develop ways to help activate and amplify the political will that achieving those goals will require (Leiserowitz, Kates and Parris 2006, 435).

Message framing and communications strategies will have to link public values with the objectives and expected outcomes of policies intended to achieve sustainability (Shields, Solar and Martin 2002; Schultz and Zelezny 2003). They will also have to incorporate values, such as equity that are rarely at the centre of public policy discourse. Such an emphasis on values is consistent with the recommendations provided by the FrameWorks Institute for advocates planning to engage problems of racial disparity (Davey 2009).

Responding in part to the American preference for equality of opportunity, FrameWorks recommends focusing on programmatic efforts to improve access to opportunity, while also noting what some of the existing barriers to opportunity just happen to be. The "opportunity frame" is consistently linked with appeals for innovation and ingenuity in developing solutions to the problems that cause, worsen, or are generated by inequity.

Their recommendations underscore the importance of calling attention to a lack of fairness with regard to systems, institutions and places, rather than with regard to individuals. Finally, their strategic framing recommendations emphasize the importance of using the concept of interdependence to reinforce the view that eliminating racial disparities is about achieving the common good, and thus, is beneficial for society as a whole (Davey 2009, 8).

In the view of many, there is little benefit in continuing to focus our communications on the threat horizon. Instead, it will be necessary for us to focus on the kinds of opportunities that we can bring into being with our collective energy and creativity.

Of course, there are risks in the development of these messages of hope and delivering them through the increasingly narrow and personalized channels of communication that the rapidly evolving commercial network sets before us. At the same time, we cannot ignore the fact that there are fundamental values that divide groups within and between nations (Dietz, Fitzgerald, and Shwom 2005). These value differences are central to the organization of ideological and political perspectives on public issues, and as a result, they must be considered in the framing of messages that might activate, or prime those value conflicts (Blamey and Braithwaite 1997).

As has been demonstrated in numerous studies, the relative weights that people place on the values of freedom and equality help to explain their affiliation with opposing political camps (Cowan et al. 2002). Those on the left tend to place a relatively higher value on equality, while those on the right tend to evaluate freedom as more important (Wilson 2005, 211). A similar opposition has been observed with regard to value clusters identified in terms of altruism, and those associated with self-enhancement, or egoism (Dietz, Fitzgerald and Shwom 2005). Thus, debates about regulations that would limit individual freedom in the interest of equal opportunity are likely to be marked by tension, and as a result, will be limited in their potential for producing influence over environmental policy decisions (Manheim 2011).

An even more critical problem may be in actually bringing about a change in the values that are used to justify, and mobilize support for what will unquestionably involve substantial change in the quality and character of the lifestyles we will be able to pursue in the future (Schultz and Selezny 2003).

It seems clear that at the global level there is not any widespread commitment to equity as a goal, nor is there much readiness to reject consumerism as a way of life (Leiserowitz, Kates and Parris 2006; Hamilton 2010). Indeed, there still appears to be a fundamental incompatibility between core values, such as prosperity and environmental protection, and individual freedom and equality, when we are faced with choosing a particular course of action (Dietz, Fitzgerald and Shwom 2005). Indeed, "these divergent values and priorities are 
rarely explicitly discussed" and as a result, we face "greater misunderstanding, intensified conflict, and gridlock" (Leiserwitz, Kates and Parris 2006, 440).

This central conflict may explain, in part why the effort to "incorporate wider questions of social justice, governance and equity" into the debates about long-standing international economic policy has not met with much success (Redclift 2005).

Part of the solution may be to focus the discourse of sustainable development on health, rather than on the economy (Paehlke 2000, 81-2). We have noted, at least in the United States, that a concern with racial disparities in health has achieved a position of prominence within the public policy environment. Beginning in 1985 when the US Secretary of Health and Human Services, Margaret Heckler, talked about the elevated risks faced by African Americans in terms of "excess death," both the nature of the disparity and its moral weight as a problem that government should address was very quickly established (Gandy 2013).

Reframing the debate in terms of health as an aspect of well-being will not be easy. Recent debates in the US about the Affordable Care Act, derisively reframed as "Obamacare," exemplify the kinds of opposition that will be mounted against expansive policy initiatives, despite advocates' claims that they are designed to limit the rising costs of medical care while expanding the social safety net.

However, if the problem of health can be framed in terms of the role that environmental quality, including the role that stress plays in the need for medical intervention, a different conversation might emerge. This kind of reframing will not be particularly easy, as there is an existing tendency within the mainstream to frame the problem of health disparities in terms of behavioural causes and solutions, much in the way that "blaming the victim" frames tend to develop in other areas of social policy (Kim, et al. 2010). The fact that societal level factors were also likely to be identified as causes and solutions for the problems of health disparities to a greater extent than other disparities that capture media attention (Kim, et al. 2010, S228S229), still provides some basis for optimism regarding this approach to framing environmental disparities.

Of course, there is still a contradiction in treating health as an expansion of both quality of life, and life expectancy. Both of these outcomes have the potential to impose additional burdens on the natural environment and its carrying capacity, unless we change the techniques and cultural practices necessary for living full and satisfying lives.

Perhaps framing a campaign in terms of expanding opportunity for all of us to live a happier, healthier life might be focused on seeking alternatives to dependence on the automobile. It would be hard to identify a technological system with a greater negative impact on the sustainability of the earth and its people. On the other hand, it would be easy to demonstrate that greater "expenditures on education, social services, health care, or the arts and entertainment... add little to the burden borne by the environment" (Paehlke 2000, 89).

Unfortunately, efforts to reframe environmental debates in an attempt to re-establish the central role of equity within the master frame will also have to confront new challenges related to the changing scales of environmental thinking. To the extent that EJ themes have been most effective in campaigns at the local level, especially in urban areas, the recent tendency for planning efforts to shift to regional and larger scales seem likely to limit the effectiveness of traditional appeals to justice (Benner and Pastor 2011).

It is suggested that "the issues likely to gain traction at a megaregional scale are different from those at a metropolitan level and may not have as immediate an impact on patterns of inequality as processes, such as housing, labor markets, and transportation decisions, that primarily unfold at a regional scale" (Benner and Pastor, 2011, 317). The problem for organizers is heightened by the fact that problems may become apparent at megaregional scale, but "the actual policy levers often exist elsewhere" (Benner and Pastor 2011, 338), perhaps even at the national level. Addressing these problems will almost certainly require the creation of even larger, more geographically dispersed and diverse coalitions. At the same time, it does not seem to mean that efforts are likely to be centred on the global or international stage.

An additional problem, at least in the United States, is that it will be difficult to mobilize public support for the development of plans and regulatory proposals in a political environ- 
ment that has become even more conservative and mistrustful of government than it had become with the rise of the neoliberalism and marketplace solutions (Alexander 2004; Gandy 2009).

Obviously, reframing the debates on sustainability in order to incorporate concerns about equity and inequality is not going to be easy. The Environmental Justice Movement represents only a small fraction of the politically engaged public that is concerned about sustainability. Nevertheless, we have identified a number of potential strategies that that can be pursued. Most important among them involve developing collective action frames that can be integrated into the master frames already being used by organizations working to reduce disparities in health, and to expand the opportunities for greater personal and community development.

We have both the opportunity, and the obligation to see what we can do to lend a hand.

\section{References}

Adams, William M. 2006. The Future of Sustainability: Re-thinking Environment and Development in the Twenty-first Century. Report of the IUCN Renowned Thinkers Meeting. Zurich, World Conservation Union.

Agyeman, Julian, Robert D. Bullard and Bob Evans. 2002. Exploring the Nexus: Bringing Together Sustainability, Environmental Justice and Equity. Space \& Polity 6 (1): 77-90.

Agyeman, Julian and Tom Evans. 2003. Toward Just Sustainability in Urban Communities: Building Equity Rights with Sustainable Solutions. The ANNALS of the American Academy of Political and Social Science 590 (November): 35-53.

Alexander, Ernest R. 2004. Capturing the Public Interest: Promoting Planning in Conservative Times. Journal of Planning Education and Research 24 (1): 102-106.

Baer, Paul. 2009. Equity in Climate-Economy Scenarios: The Importance of Subnational Income Distribution. Environmental Research Letters 4 (1): 1-11. Accessed February 23, 2013. http://iopscience.iop.org/1748-9326/4/1/015007/pdf/1748-9326_4_1_015007.pdf

Barnett, Jon, Simon Lambert and lan Fry. 2008. The Hazards of Indicators: Insights from the Environmental Vulnerability Index." Annals of the Association of American Geographers 98 (1): 102-119.

Bartels, Larry. 2008. Unequal Democracy: The Political Democracy of the New Guilded Age. Princeton, NJ: Princeton University Press.

Beamish, Thomas D. and Amy J. Luebbers. 2009. Alliance Building Across Social Movements: Bridging Difference in a Peace and Justice Coalition. Social Problems 56 (4): 647-676.

Benford, Robert D. and David A. Snow. 2000. Framing Processes and Social Movements: An Overview and Assessment." Annual Review of Sociology 26: 611-639.

Benner, Chris and Manuel Pastor. 2011. Moving on Up? Regions, Megaregions, and the Changing Geography of Social Equity Organizing. Urban Affairs Review 47(3): 315-348.

Bithas, Kostas. 2008. The Sustainable Residential Water Use: Sustainability, Efficiency and Social Equity. The European Experience. Ecological Economics 68 (1-2): 221-229.

Blamey, Russell K. and Valerie A. Braithwaite. 1997. A Social Values Segmentation of the Potential Ecotourism Market. Journal of Sustainable Tourism 5 (1): 29-45.

Boulanger, Paul-Marie. (2008) Sustainable Development Indicators: A Scientific Challenge, a Democratic Issue." S.A.P.I.EN.S 1(1): 45-59.

Boyce, James K. 2008. Is Inequality Bad for the Environment? Research in Social Problems and Public Policy 15: 267-288.

Brulle, Robert J. 2010. Politics and the Environment. In The Handbook of Politics: State and Civil Society in Global Perspective, edited by Kevin T. Leicht and J. Craig Jenkins, 385-406. New York: Springer.

Brulle, Robert J. and David N. Pellow. 2006. Environmental Justice: Human Health and Environmental Inequalities." Annual Review of Public Health 27: 103-24.

Brundtland, Gro H. 1987. World Commission on Environment and Development: Our Common Future. New York: Oxford University Press.

Bullard, Robert D. 1990. Dumping in Dixie: Race, Class, and Environmental Quality. Boulder, CO: Westview Press.

Bullard, Robert D. 1993. Anatomy of Environmental Racism and the Environmental Justice Movement, In Environmental Racism: Voices from the Grassroots, edited by Robert Bullard, 15-23. Boston: South End Press. 
Bullard, Robert. and G. Johnson (2000). Environmentalism and Public Policy: Environmental Justice: Grassroots Activism and its Impact on Public Policy Decision Making. Journal of Social Issues 56 (3): 555-578.

Burdon, Peter. 2010. The Rights of Nature: Reconsidered. Australian Humanities Review 49 (November): 69; U. of Adelaide Law Research Paper No. 2011-010. Accessed April 12, 2013. http://ssrn.com/abstract=1709015

Carragee, Kevin M. and Wim Roefs. 2004. The Neglect of Power in Recent Framing Research. Journal of Communication 54 (2): 214-233.

Clinton, William J. 1994. Federal Actions to Address Environmental Justice in Minority Populations and Low-Income Populations, Executive Order 12898. Washington, DC: Office of the President.

Colten, Craig E. 2007. Environmental Justice in a Landscape of Tragedy. Technology in Society 29: 173-179.

Cowan, Gloria, Miriam Resendez, Elizabeth Marshall and Ryan Quist. 2002. Hate Speech and Constitutional Protection: Priming Values of Equality and Freedom." Journal of Social Issues 58 (2): 247263.

Cutts, Bethany B., Kate J. Darby, Christopher G. Boone and Alexandra Brewis. 2009. City Structure, Obesity, and Environmental Justice: An Integrated Analysis of Physical and Social Barriers to Walkable Streets and Park Access. Social Science \& Medicine 69: 1314-1322.

Dauvergne, Peter. 2008. The Shadows of Consumption: Consequences for the Global Environment. Cambridge, MA: The MIT Press.

Dauvergne, Peter. 2010. The Problem of Consumption. Global Environmental Politics 10 (2): 1-10.

Davey, Lynn. 2009. Strategies for Framing Racial Disparities: The Effect of Frame Choices on Support for Race-Based Policies. A Frameworks Institute Message Brief. Washington, DC: FrameWorks Institute.

Davidson, Kathryn. 2011. A Typology to Categorize the Ideologies of Actors in the Sustainable Development Debate. Sustainable Development. Prepublication acquired April 12, 2013. http://onlinelibrary.wiley.com/doi/10.1002/sd.520/pdf

Dietz, Thomas, Amy Fitzgerald, and Rachael Shwom. 2005. Environmental Values. Annual Review of Environment and Resources 30: 335-372.

Dilworth, R., R. Stokes, et al. 2011. The Place of Planning in Sustainability Metrics for Public Works: Lessons from the Philadelphia Region. Public Works Management \& Policy 16 (1): 20-39.

Dollar, David. 2007. Globalization, Poverty and Inequality Since 1980. In Global Inequality: Patterns and Explanations, edited by David Held and Ayse Kaye, 73-103. New York: Polity Press.

Downey, Liam and B. Hawkins. 2008. Race, Income and Environmental Inequality in the United States. Sociological Perspective 51 (4): 759-781.

Eakin, Hallie and Amy L. Luers. 2006. Assessing the Vulnerability of Social-Environmental Systems. Annual Review of Environment and Resources 31: 365-94.

Farrow, Scott. 1998. Environmental Equity and Sustainability: Rejecting the Kaldor-Hicks Criteria. Ecological Economics 27: 183-8.

Fast, Stewart. 2009. The Biofuels Debate: Searching for the Role of Environmental Justice in Environmental Discourse. Environments Journal 37(1): 83-100.

Fraser, Nancy. 2007. Reframing Justice in a Globalizing World. In Global Inequality: Patterns and Explanations, edited by David Held and Ayse Kaye, 252-272. New York: Polity Press.

Gamson, William A. and Micah L. Sifry. 2013. The \#Occupy Movement: An Introduction. The Sociological Quarterly 54: 159-228.

Gandy, Oscar H., Jr. 1982. Beyond Agenda Setting: Information Subsidies and Public Policy. Norwood, NJ: Ablex.

Gandy, Oscar H., Jr. 2009. Coming to Terms with Chance: Engaging Rational Discrimination and Cumulative Disadvantage. Burlington, VT: Ashgate Publishing.

Gandy, Oscar H., Jr. 2013 (in press). Framing Inequality in Public Policy Discourse: The Nature of Constraint. In The Oxford Handbook of Political Communication, edited by Kate Kenski and Kathleen Hall Jamieson. New York: Oxford University Press.

Giddens, Anthony. 2009. The Politics of Climate Change. Cambridge, UK: Polity Press.

Giddings, Bob, Bill Hopwood and Geoff O'Brien. 2002. Environment, Economy and Society: Fitting Them Together into Sustainable Development. Sustainable Development 10: 187-196.

Hacker, Jacob S. and Paul Pierson. 2010. Winner-Take-All Politics: Public Policy, Political Organization, and the Precipitous Rise of Top Incomes in the United States. Politics \& Society 38 (2): 152204.

Hamilton, Clive. 2010. Consumerism, Self-Creation and Prospects for a New Ecological Consciousness. Journal of Cleaner Production 18: 571-575. 
Holt, Diane and Ralf Barkemeyer. 2012. Media Coverage of Sustainable Development Issues-Attention Cycles or Punctuated Equilibrium? Sustainable Development 20 (1): 1-17.

Hopwood, Bill, Mary Mellor and Geoff O'Brian. 2005. Sustainable Development: Mapping Different Approaches. Sustainable Development 13 (1): 38-52.

Jensen, Lois. 2010. Millennium Development Goals Report 2010. New York: United Nations Department of Economic and Social Affairs.

Juris, Jeffrey. 2012. Reflections on \#Occupy Everywhere: Social Media, Public Space, and Emerging Logics of Aggregation. American Ethnologist 39 (2): 259-279.

Kang, Helen H. 2009. Pursuing Environmental Justice: Obstacles and Opportunities---Lessons from the Field. Journal of Law \& Policy 31: 121-156.

Kim, Annice E., Shiriki Kumanyika, Daniel Shive, Uzy Igweatu and Son-Ho Kim. 2010. Coverage and Framing of Racial and Ethnic Health Disparities in US Newspapers, 1996-2005. American Journal of Public Health 100(S1): S224-S231.

Kreig, Eric J. and Daniel R. Faber. 2004. Not so Black and White: Environmental Justice and Cumulative Impact Assessments. Environmental Impact Assessment Review 24: 667-694.

Leiserowitz, Anthony A., Robert W. Kates and Thomas M. Parris. 2006. Sustainability Values, Attitudes and Behaviors: A Review of Multinational and Global Trends. Annual Review of Environment and Resources 31: 413-44.

Lynch, John, George D. Smith, Sam Harper, Marianne Hillemeier, Nancy Ross, George A. Kaplan and Michael Wolfson. 2004. Is Income Inequality a Determination of Population Health? Part 1. A Systematic Review. The Milbank Quarterly 82 (1): 5-99.

Manes, Christopher. 1992. Nature and Silence. Environmental Ethics 14 (Winter): 339-350.

Manheim, Jarol B. 2011. Strategy in Information and Influence Campaigns: How Policy Advocates, Social Movements, Insurgent Groups, Corporations, Governments and Others Get What They Want. New York: Routledge.

Mayer, Audrey L. 2008. Strengths and Weaknesses of Common Sustainability Indices for Multidimensional Systems. Environment International 34: 277-291.

Maxwell, Richard and Toby Miller. 2012. Greening the Media. New York: Oxford University Press.

Miller, M. Mark and Bonnie P. Riechert. 2000. Interest Group Strategies and Journalistic Norms: News Media Framing of Environmental Issues. In Environmental Risks and the Media, edited by Stuart Allan, Barbara Adam and Cynthia Carter, 45-54. New York: Routledge.

Morello-Frosch, Rachel, Miriam Zuk, Michael Jerrett, Bhavna Shamasunder and Amy D. Kyle. 2011. Understanding the Cumulative Impacts of Inequalities in Environmental Health: Implications for Policy. Health Affairs 30 (5): 879-887.

Nelson, Donald R., W. Neil. Adger and Katrina Brown. 2007. Adaptation to Environmental Change: Contributions of a Resilience Framework. Annual Review of Environment and Resources 32: 395419.

Nelson, Thomas E. and Elaine A. Willey. 2003. Issue Frames That Strike a Value Balance: A Political Psychology Perspective. In Framing Public Life: Perspectives on Media and Our Understanding of the Social World, edited by Stephen D. Reese, Oscar H. Gandy, Jr. and August E. Grant, 245-266. Mahwah, NJ: Lawrence Erlbaum Associates.

Nisbet, Matthew C. 2010. Knowledge Into Action: Framing the Debates Over Climate Change and Poverty. In Doing News Framing Analysis: Empirical and Theoretical Perspectives, edited by Paul D'Angelo and Jim A. Kuypers, 43-83. New York: Routledge.

Noakes, John A. and Hank Johnston. 2005. Frames of Protest: A Road Map to a Perspective. In Frames of Protest: Social Movements and Their Framing Perspective, edited by Hank Johnston and John Noakes, 1-29. Lanham, MD: Rowman \& Littlefield Publishers.

Okrent, David. 1999. On Intergenerational Equity and Its Clash with Intragenerational Equity and on the Need for Policies to Guide the Regulation of Disposal of Wastes and Other Activities Posing Very Long-Term Risks. Risk Analysis 19 (5): 877-901.

Paehlke, Robert C. 2000. Environmental Values and Public Policy. In Environmental Policy: New Directions for the Twenty-First Century, $4^{\text {th }}$ Edition, edited by Norman J. Vig and Michael E. Kraft, 7797. Washington, DC: CQ Press.

Pan, Tai-Chin and Jaehng-Jung Kao. 2009. Inter-Generational Equity Index for Assessing Environmental Sustainability: An Example on Global Warming. Ecological Indicators 9 (4): 725-731.

Pan, Zhongdang and Gerald M. Kosicki. 2001. Framing as a Strategic Action in Public Deliberation. In Framing Public Life: Perspctives on Media and Our Understanding of the Social World, edited by Stephen D. Reese, Oscar H. Gandy, Jr. and August E. Grant, 35-65. Mahwah, NJ: Lawrence Earlbaum Associates. 
Pastor, Manuel and Rhonda Ortiz. 2009. Making Change: How Social Movements Work--and How to Support Them. Los Angeles: Program for Environmental and Regional Equity, University of Southern California.

Pavel, M. Palovma. 2008. Breaking Through to Regional Equity. Race, Poverty \& The Environment, Fall: 29-31.

Pellow, David N. 1999. Framing Emerging Environmental Movement Tactics: Mobilizing Consensus, Demobilizing Conflict. Sociological Forum 14 (4): 659-683.

Pew Research Center. 2009. Trends in Political Values and Core Attitudes: 1987-2009: Independents Take Center Stage in Obama Era. Washington, DC: The Pew Research Center for The People \& the Press.

Pollock, John. 2007. Tilted Mirrors: Media Alignment with Political and Social Change: A Community Structure Approach. Cresskill, NJ: Hampton Press.

Popescu, Mihaela and Oscar H. Gandy, Jr. 2004. Whose Environmental Justice? Social Identity and Institutional Rationality. Journal of Environmental Law and Litigation 19 (1): 141-192.

Povlsen, Lene, Ina K. Borup and Elisabeth Fosse. 2011. The concept of "equity" in health-promotion articles by Nordic authors--A matter of some confusion and misconception. Scandinavian Journal of Public Health 39 (Suppl 6): 50-56.

Pulver, Simone and Stacy D. VanDeveer. 2009. "Thinking about tomorrows": Scenarios, Global Environmental Politics, and Social Science Scholarship. Global Environmental Politics 9 (2): 1-13.

Quental, Nuno, Julia M. Lourenco and Fernando N. da Silva. 2011. Sustainable Development Policy: Goals, Targets and Political Cycles. Sustainable Development 19 (1): 15-29.

Redclift, Michael. 2005. Sustainable Development (1987-2005): An Oxymoron Comes of Age. Sustainable Development 13 (4): 212-227.

Schultz, P. Wesley and Lynette Zelezny. 2003. Reframing Environmental Messages to be Congruent with American Values. Human Ecology Review 10 (2): 126-136.

Shields, D. J., S. V. Solar and W. E. Martin. 2002. The Role of Values and Objectives in Communicating Indicators of Sustainability. Ecological Indicators 2 (1-2): 149-160.

Simon, David R. 2000. Corporate Environmental Crimes and Social Inequality: New Directions for Environmental Justice Research. The American Behavioral Scientist 43 (4): 633-645.

Singh, Rajesh K., H.R. Murty, S.K. Gupta and A.K.Dikshit. 2009. An Overview of Sustainability Assessment Methodologies. Ecological Indicators 9 (2): 189-212.

Sneddon, Chris, Richard B. Howarth and Richard B. Norgaard. 2006. Sustainable Development in a Post-Brundtland World. Ecological Economics 57 (2): 253-268.

Snow, David A., E. Burke Rochford, Jr., Steven K. Worden and Robert D. Benford. 1986. Frame Alignment Processes, Micromobilization, and Movement. Amerian Sociological Review 51 (4): 464481.

STAR Communities. 2012. STAR Community Rating System. Version 1.0. Washington, D.C.: STAR Communities. Accesed on April 13, 2013. http://www.starcommunities.org/rating-system

Stiglitz, Joseph E., Amartya Sen and Jean-Paul Fitoussi. 2009. Report by the Commission on the Measurement of Economic Performance and Social Progress. Paris: International Commission on Measurement of Economic Performance and Social Progress.

Sutcliffe, Bob. 2007. The Unequalled and Unequal Twentieth Century. In Global Inequality: Patterns and Explanations, edited by David Held and Ayse Kaye, 50-72. New York: Polity Press.

Sze, Julie and Jonathan K. London. 2008. Environmental Justice at the Crossroads. Sociology Compass 2 (4): 1331-1354.

Taylor, Dorceta E. 2000. The Rise of the Environmental Justice Paradigm: Injustice Framing and the Social Construction of Environmental Discourses. American Behavior Scientist 43 (4): 508-580.

Tichenor, Phillip J., George A. Donohue, Clarice Olien and Peter Clarke. 1980. Community Conflict and the Press. Beverly Hills, CA: Sage.

United States Environmental Protection Agency (EPA). 1922. Environmental Equity. Reducing Risk for All Communities. Volume 1: Workgroup Report to the Administrator. EPA230-R-92-008. Washington, DC: United States Environmental Protection Agency.

Vandenbergh, Michael P. and Brooke Ackerly. 2008. Climate Change: The Equity Problem. Virginia Environmental Law Journal 26: 53-74.

Van Stekelenburg, Jacqueline. 2012. The Occupy Movement: Product of This Time. Development 55 (2): 224-231.

Wade, Robert H. 2007. Should We Worry About Income Inequality? In Global Inequality: Patterns and Explanations, edited by David Held and Ayse Kaye, 104-131. New York: Polity Press.

Walker, Gordon. 2009a. Globalizing Environmental Justice: The Geography and Politics of Frame Contextualization and Evolution. Global Social Policy 9(3): 355-382. 
Walker, Gordon. 2009b. Beyond Distribution and Proximity: Exploring the Mutual Spatialities of Environmental Justice. Antipode 41 (4): 614-636.

Walker, Gordon and Malcolm Eames. 2006. Environmental Inequalities. Cross-Cutting Themes for the ESRC/NERC Transdisciplinary Seminar Series on Environmental Inequalities 2006-8 (Vol. 8). Discussion paper accessed April 12, 2013.

http://www.geography.lancs.ac.uk/envjustice/eiseminars/downloads/ei_discussion.pdf

Wilkinson, Richard G. and Kate E. Pickett. 2009. Income Inequality and Social Dysfunction. Annual Review of Sociology 35: 493-511.

Wilson, Marc S. 2005. A Social-Value Analysis of Postmaterialism. Journal of Social Psychology 145 (2): 209-224.

\section{About the Author}

Oscar H. Gandy, Jr.

is emeritus professor of communication with the University of Pennsylvania. 